\title{
反射型光電センサを用いた動脈探索法*
}

\author{
大田 慎一郎*1, 安田 利 貴*2, 下村翔 大*3 \\ 末永弘美*2, 斉藤俊*1
}

\section{Development of an Artery Searching Method by Using Reflection Photoplethysmography}

\author{
Shinichiro OTA*4, Toshitaka YASUDA, Shouta SHIMOMURA, \\ Hiromi SUENAGA and Takashi SAITO \\ ${ }^{* 4}$ Applied Medical Engineering Sciences, Graduate School of Medicine, Yamaguchi University, \\ 2-16-1 Tokiwadai, Ube-shi, Yamaguchi, 755-8611 Japan
}

\begin{abstract}
It is important for non-invasive measurement of arterial stiffness to set a pressure sensor on the center of artery. In previous our study, moving the reflection optical sensor on an inner side of wrist, we observed inversion phenomena that a dicrotic wave and a percussion wave of reflection photoplethysmography (incident wavelength of 530,650 and $810 \mathrm{~nm}$ ) were turned over. If the relationship between inversion phenomena and a location of artery is clarified, we expect that inversion phenomena will be applied to use an artery detection system. The purpose of this study is to clarify the mechanism of inversion phenomena, and to suggest the artery searching method by using inversion phenomena. In this study, we investigate the mechanism of inversion phenomena by a measurement of pulse wave using the reflection optical sensor and a numerical analysis of light propagation in a wrist, and examined this method to estimate a artery position by this measurement. Numerical analysis results indicated the cause of inversion phenomena is influence of scattering. In the results of measurement, inversion phenomena occur under the optical sensor setting on the center of artery. In conclusion, it is available for an artery searching method to use reflection photoplethysmography of incident wavelength $530 \mathrm{~nm}$ and $810 \mathrm{~nm}$.
\end{abstract}

Key Words: Photoplethysmograpy, Artery Searching, Medical Equipment, Noninvasive Measurement, Optical Measurement

\section{1. 緒 論}

非侵襲的に動脈硬度を推定することは, 循環器特性 を診断するのに有効な手段となる。これまで我々は, 反射型光電センサを用いて測定される脈波 (光電脈波) から，動脈硬度推定に関するアルゴリズムの開発を試 みた (1)(2).その結果, 生体模擬血管を用いた評価実験 から, 模擬血管の肉厚, 直径の影響を除去可能な粘弾 性指標を提案した. しかしながら，粘弾性特性の検出 のためには血圧変化を高精度で測定することが必要で あり，表皮から動脈位置を把握することが重要となる (3)

非侵襲な光を用いた血管探索法に関しては静脈注射

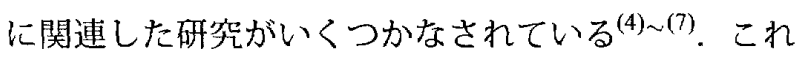
らは血管周辺組織と比べて，血管の吸収，散乱特性が

\footnotetext{
*原稿受付 2008 年 8 月 20 日.

*1 正員, 山回大学大学院垁学系研究科( - 755-8611 宇部市常 盤台 $2-16-1)$.

*2 山口大学大学院医学系研究科.

*3 山口大学工学部機械工学科.

E-mail : j005ug@yamaguchi-u.ac.jp
}

異なることを利用しており，Nakamachi らは静脈を対 象とし，静的な散乱光強度分布を用いたマイクロオー ダーの三次元㨲査システムを提案している(6). しかし ながら, 小, 中, 大動脈を対象とした場合, 静脈より 比較的梁い場所に位置していることが多く, 動脈と静 脈の区別が困難であるため，同手法の適用は難しい． ここで, 動脈は膨張, 収縮の散乱光強度変化が生じる ため,この動的な変化を利用して, 動脈位置の推定に 用いることが考えられる.

我々は，血液の酸素飽和度の影響を受けずにへモグ ロビン濃度のみに依存する波長 $(\lambda) 810 \mathrm{~nm}$ を基準に吸 収, 散乱の影響が大きくなる波長として $650 \mathrm{~nm}, 530 \mathrm{~nm}$ の光電脈波を測定し, 波長 $530 \mathrm{~nm}$ の受発光部を動脈 に近づけたときに波長 $650 \mathrm{~nm}, 810 \mathrm{~nm}$ の光電脈波の 波形と異なり.形状が反転する現象 (反転現象) が測定さ れることを見出した ${ }^{(8)(9)}$.この反転現象を用いること で, 光電脈波の波形から動脈位置が検出可能になると 考えられる. しかしながら, 反転現象の発生要因が不 明なこと，血管とセンサの位置関係ならび，入射光波 長との関係が不明瞭な点が多い. 
そこで, 本研究の目的は, 光電脈波の測定と生体を 模擬した光散乱解析を用いて反転現象を明らかとし, 反転現象を用いて皮膚表面から動脈上部の中心位置を 推定する非侵襲動脈位置探索法を提案することである. 本論文では異なる吸収, 散乱特性を有する波長 $530 \mathrm{~nm}$, $650 \mathrm{~nm}$ と $810 \mathrm{~nm}$ の光電脈波の測定, 及び二次元光散 乱解析を行う. まず, 二次元光散乱解析と光電脈波測 定の振幅を比較し，二次元光散乱解析の妥当性につい て検証した. 次に，二次元光散乱解析を行い，反転現 象の発生要因について調べた. そして, 光電脈波測定 から動脈位置と反転現象の関係を明らかとし, 反転現 象を用いる動脈位置探索法について検討した。

\section{2. 光電脈波測定実験}

2.1 実験方法 光電脈波測定実験は, 成人男性の 右手撓骨動脈を対象とし，インフォームドコンセント を得て行う. 図 1 に示す実験装置は, 発光部 LED(Light Emitting Diode) と受光部 PD(Photo Diode) を有する光 電センサ (YU01; オプトテクノ), 光ファイバーの受発光 部固定治具, マイクロメーター，腕保持台とコンピュー タから構成される，超音波断層測定装置 (Prosound SSD6500SV; アロカ) で動脈位置上部をマーキングを 行い，動脈の中心位置を定める. 受発光部の間隔 $S D$ (Separate Distance) を $2 \mathrm{~mm}$, 光電センサは吸収, 散乱 特性の異なる波長 $530 \mathrm{~nm}, 650 \mathrm{~nm}$ と $810 \mathrm{~nm}$ とする. 図 1 に示すように，発光部が動脈の真上にくる位置を原 点とし，原点を中心 $\pm 4 \mathrm{~mm}$ までの範囲を $1 \mathrm{~mm}$ 間隔で 光ファイバ保持具を動脈軸の垂直方向に皮膚表面をマ イクロゲージを用いて水平移動させ，皮膚表面から受 発光部固定治具で押えて, 計九点を測定する. 解析で 求める散乱光強度変化量 $\Delta \Phi$ は光䉓脈波により測定す る散乱光強度変化量 $\Delta I$ に対応しているため, それぞ れの $\Delta \Phi$ と $\Delta I$ について相対的な比較が可能となる.

サンプリング周波数は $2 \mathrm{kHz}$, 測定時間 $35 \mathrm{~s}$ とし, 反 射式光電センサを用いて測定された光電脈波の交流電 源ノイズの除去及び，生体の動作から発生する歪みを 除去するため, $0.5 \sim 50 \mathrm{~Hz}$ のバンドパスフィルタを適 用し，周波数成分を除去する.

2.2 散乱光強度の振幅特性 散乱光強度の測定 值と光散乱解析值を比較するため, 测定值の散乱光強 度の振幅值を算出し，受発光部の位置を变化させた場 合の散乱光強度の振幅特性を調べる.

図 2 に光電脈波の一例を示す．横軸は時間，縦軸は 散乱光強度 $I$ 単位 $\mathrm{V}$ である.ここで，十周期における 光電脈波の平均振幅值 $|\Delta I|$ 単位 $\mathrm{V}$ を算出する.

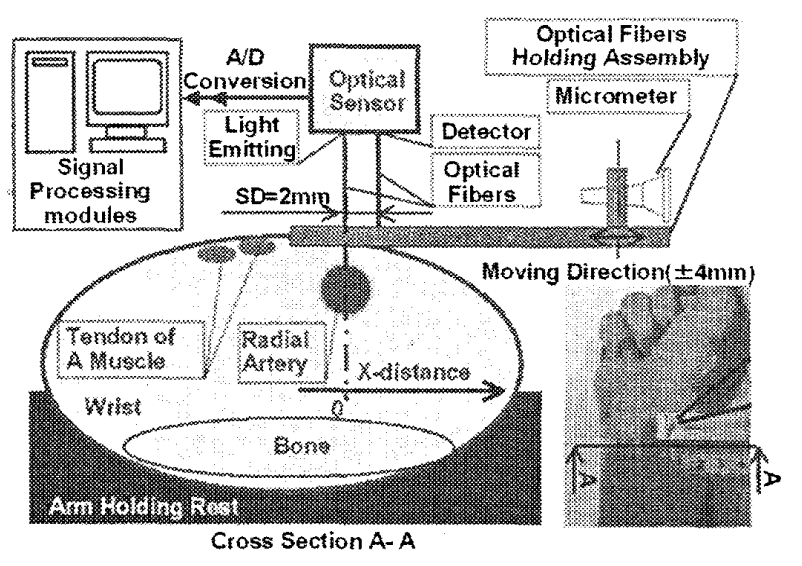

Fig. 1 An experimental set-up.

2.3 超音波脈波形-光電脈波波形の相関性 超音 波波形と光電脈波波形を決定係数 $R^{2}$ を用いて, 反転 の有無を脈波形状の相関性から評価する.

まず，図３に示す二つの波形を比較するために各周 期において，それぞれの脈波形を式(1)により無次元 化することで規格化する.

$$
f^{\prime}(t)=\frac{f(t)-f_{A V E}}{A m p}
$$

$f^{\prime}(t)$ は無次元化後の値， $f(t)$ は測定値， $f_{A V E}$ は一周 期の最小值と最大值の平均值, Amp は一周期の振幅を 示す. 次に，無次元化された一周期の超音波脈波波形 と十周期に打ける光電脈波波形の共分散とそれぞれの 標準偏差から決定係数 $R^{2}$ を求好. 同樣に，無次元 化された一周期の超音波脈波反転波形と十周期に招け る光電脈波波形の共分散とそれぞれの標準编差から決 定係数 $R^{2}$ を求める.

2.4 二波長光源を用いた動脈位置探査法 波長 $530 \mathrm{~nm}$ と $810 \mathrm{~nm}$ の光電脈波波形を決定係数 $R^{2}$ を用い て，反転の有無を脈波形状の相関性から評価し，動脈 位置探査への有效性を検討する.

まず，2.3節と同様に，式(1)により無次元化された 一周期の波長 $810 \mathrm{~nm}$ の光電脈波波形と十周期におけ る光電脈波波形の共分散とそれぞれの標準偏差から決 定係数 $R^{2}$ を求める. 同様に，無次元化された一周期 の波長 $810 \mathrm{~nm}$ の光電脈波反転波形と十周期に扔ける 波長 $530 \mathrm{~nm}$ の光電脈波波形の共分散とそれぞれの標 準偏差から決定係数 $R^{2}$ を求める.

\section{3. 光散乱解析実験}

3.1 光拡散方程式生体組織における定常状態 の光散乱は輸送方程式を光拡散近似された式 (2)に示 す光拡散方程式で表される(10).

$$
\nabla[D(r) \nabla \phi(r)]-\mu_{a} \phi(r)+S(r)=0
$$




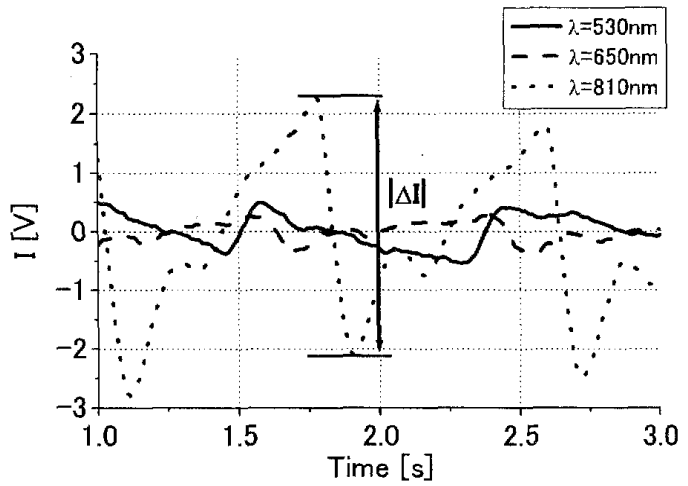

Fig. 2 An example of measurement of reflected light intensity under the optical sensor setting on the center of a artery

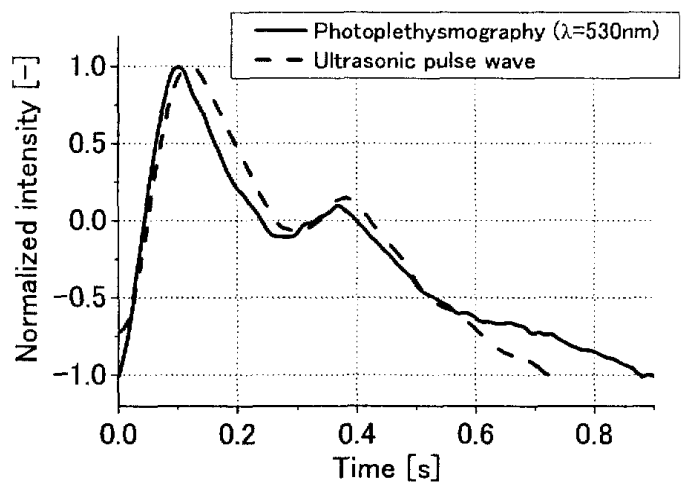

Fig. 3 The relationship between $\lambda=530 \mathrm{~nm}$ photoplethysmograhy and ultrasonic palse wave.

$\phi(r)$ 単位 $\mathrm{W} / \mathrm{mm}^{2}$ は位置 $r$ 単位 $\mathrm{mm}$ における積分強 度, $S(r)$ 単位 $\mathrm{W} / \mathrm{mm}^{3}$ は内部光源, $D(r)=1 /\left(3 \mu_{s}^{\prime}(r)\right)$ 単位 $\mathrm{mm}$ は拡散係数, $\mu_{a}$ 単位 $1 / \mathrm{mm}$ は吸収係数, $\mu_{s}^{\prime}$ 単位 $1 / \mathrm{mm}$ は等価散乱係数を示している. 式 (2) を 中心差分を用いて離散化し，SOR 法 (Successive Over Relaxation) を用いて二次元の数值解析を行った. 緩和 係数は 1.9 とし，相対残差は $10^{-7}$ とする.

3.2 橈骨動脈モデル 超音波の断層画像を基に 図 4 に示す解析モデルを構築する. 測定との比較を 行うため, 断層画像から表皮から血管の中心までの距 離 (動脈深さ) を $\mathrm{d}=5.31 \mathrm{~mm}$ とし, 反転現象について 検討するため異なる動脈深さを $\mathrm{d}=3,4,7 \mathrm{~mm}$ として解 析する. さらに，超音波により測定した血管径変化か ら血管内径の最小值, 最大值を $R=2.38,2.46 \mathrm{~mm}$ と し，二通り解析することで，血管径変化を模擬する. 血管壁の厚みは大腿動脈の血管内径に対する厚みが約 $10 \%$ であることから ${ }^{(10)}$, 橈骨動脈を模擬したモデル

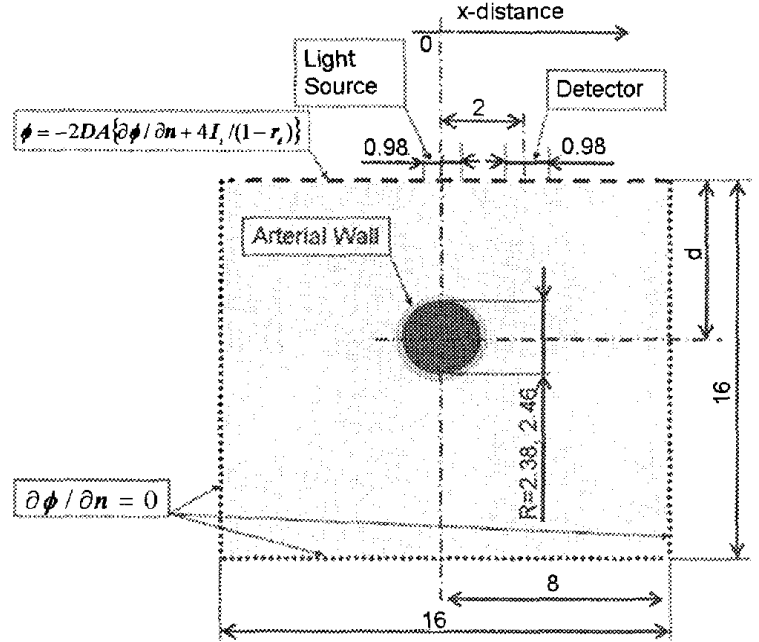

Fig. 4 Analysis model

も同様に血管内径に対する厚みを $10 \%$ に設定し，血 管内径 $R=2.38 \mathrm{~mm}$ のとき $0.24 \mathrm{~mm}, R=2.46 \mathrm{~mm}$ のとき $0.25 \mathrm{~mm}$ とした．計算領域を $16 \mathrm{~mm} \times 16 \mathrm{~mm}$ ，メッシュ 間隔を $0.01 \mathrm{~mm}$ ，内部光源を $S(r)=0$ とした，発光点に は $I_{0}=100 \mathrm{~W} / \mathrm{mm}^{3}$ の連続光を入射させ, 受光点におけ る散乱光強度は $\Phi=-D(\partial \phi / \partial n)$ 単位 $\mathrm{W} / \mathrm{mm}^{2}$ で表さ れる，境界条件は，発光面において内部反射を考慮し て以下のように設定した.

$$
\begin{gathered}
\Phi=2 D A\left\{\frac{\partial \phi}{\partial n}+\frac{4 I_{0}}{\left(1-r_{d}\right)}\right\}, A=\frac{1+r d}{1-r d}, n_{r e f}=\frac{n_{b}}{n_{a}}, \\
r_{d}=-1.440 n_{r e f}^{-2}+0.710 n_{r e f}^{-1}+0.668+0.0636 n_{r e f},
\end{gathered}
$$

ここで, 生体の属折率 $n_{b}=1.5$, 大気の屈折率 $n_{a}=1.0 \mathrm{~K}$ 設定し, 発光面以外の境界条件は $\partial \phi / \partial n=0$ とした. 生体組織の光物性值は表 1 を用いる. 解析により算出 された散乱光強度 $\Phi$ は図 4 に示す受発光位置における 光ファイバのコア径 $0.98 \mathrm{~mm}$ の平均值とし, 最大血管 径における散乱光強度を $\Phi_{M A X}$, 最小血管径における 散乱光強度を $\Phi_{M I N}$ とし, 径変化時の散乱光強度変化 量 $\Delta \Phi=\Phi_{M A X}-\Phi_{M I N}$ 単位 $\mathrm{W} / \mathrm{mm}^{2}$ を算出する. 解析 条件は光電脈波測定実験と同様に $S D=2 \mathrm{~mm}$ とし，発 光点が動脈の真上にくる位置を原点とし，原点を中心 $\pm 4 \mathrm{~mm}$ までの範囲を $1 \mathrm{~mm}$ 間隔で, 計九点の $\Delta \Phi$ を求 める. 解析で求める散乱光強度変化量 $\Delta \Phi$ は光電脈波 により測定する散乱光強度変化量 $\Delta I$ に対応している

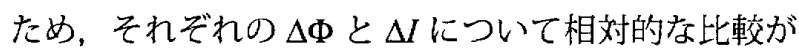
可能となる。

図 5 は $\mathrm{R}=2.38 \mathrm{~mm}$, 波長 $530 \mathrm{~nm}$ における積分光強 度分布を示している.これより，図５に示す動脈設置 位置で四収、散乱により積分光強度の等高線の円状に 密になっていることが確認される. 
Table 1 Optical Properties ${ }^{(12)(13)(14)}$

\begin{tabular}{rc|cc}
\hline Tissue & $\begin{array}{c}\text { Wavelength } \\
\mathrm{nm}\end{array}$ & $\begin{array}{c}\mu_{a} \\
\mathrm{~mm}^{-1}\end{array}$ & $\begin{array}{c}\mu^{\prime}{ }^{-1} \\
\mathrm{~mm}^{-1}\end{array}$ \\
\hline \hline Arteral & 530 & 1.00 & 6.5 \\
Wall & 650 & 0.40 & 4.5 \\
& 810 & 0.30 & 2.9 \\
\hline Blood & 530 & 24.60 & 1.88 \\
$\mathrm{H}_{2} 0$ & 650 & 0.98 & 1.63 \\
Hct. $=0.41 \%$ & 810 & 0.82 & 1.53 \\
\hline Subcutaneous & 530 & 0.14 & 1.48 \\
adipose & 650 & 0.12 & 1.28 \\
& 810 & 0.11 & 1.11 \\
\hline
\end{tabular}

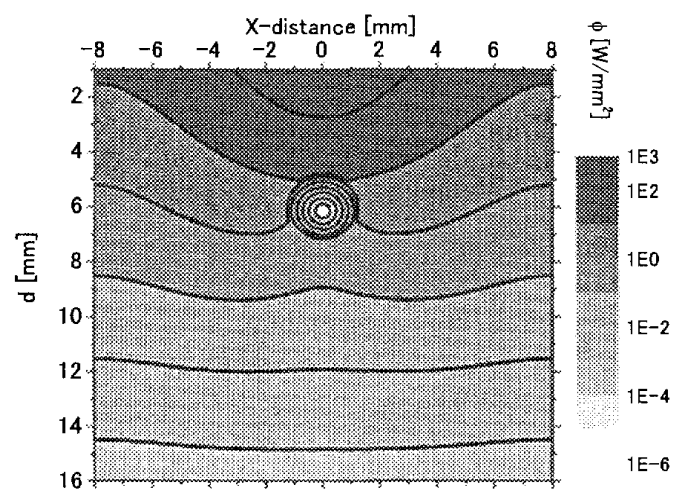

Fig. 5 Distribution of fluence rate $\phi$ with $R=2.38 \mathrm{~mm}$.

3.3 散乱光強度の振幅特性 散乱光強度の測定 值と光散乱解析值を比較するため, 散乱光強度の振幅 の光散乱解析值 $|\Delta \Phi|$ 単位 $W / \mathrm{mm}^{2}$ を算出する.

3.4 反転現象の検証 反転現象の要因を検証す るため, 3.2 節と同様に散乱光強度変化量 $\Delta \Phi$ を算出

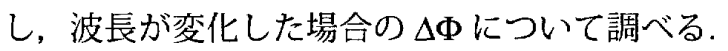

\section{4. 結果と考察}

$4 \cdot 1$ 散乱光強度の振幅特性図 6(a)(b) は光電脈 波測定実験と光散乱解析実験の結果を示している. 横 軸は発光点位置, 図 6(a) の縦軸は $|\Delta I|$, 図 6(b) の縦軸 は $|\Delta \Phi|$ であり，Aが受発光間の中心位置に血管がある 場合を示している，図6(a)より，A の場合に全波長で 最大值を示していることが確認される．これは図 6(b) の光散乱解析結果と傾向が一致しているおり, 受発光 点の中心に血管が位置している場合に血管径変化の影 響が散乱光強度変化に最も影響を与えていることが考

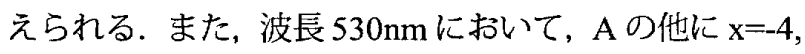
$3 \mathrm{~mm}$ において極大值が確認される.これは表 1 に示 すように波長 $530 \mathrm{~nm}$ は $650 \mathrm{~nm}$ と $810 \mathrm{~nm}$ より比較的散
乱，吸収が大きいことから，皮膚の毛細血管の影響が 反映されていると考えられる。しか，他の波長と同 様にAに扔いて最大值を示していることから，測定結 果は妥当と考えられる. 一方, 波長 $650 \mathrm{~nm}$ と $810 \mathrm{~nm}$ は $\mathrm{x}=-4 \mathrm{~mm}$ に打いて波長 $530 \mathrm{~nm}$ と同様に毛細血管の 影響がほとんど現れていない，これは波長 $650 \mathrm{~nm}$ と $810 \mathrm{~nm}$ は波長 $530 \mathrm{~nm}$ よりも樑い領域の血管壁と血液 の変動を検出している.したがって，表面付近の毛細 血管の影響よりも $\mathrm{x}=-1 \mathrm{~mm}$ を最大值とする動脈の拍動 による光散乱強度変化を検出し易く, 相刘的に毛細血 管の影響が小さくなったと考えられる.

以上より, 光電脈波測定実験と光散乱解析実験が同 様の傾向を示していることから，本解析モデルは橈骨 動脈を充分に模擬できていると考えられる.

4.2 反転現象の検証 2.2 節の図 2 の測定結果の 一例を示す. 脈波形状の特徴として, 最大ピーク点で ある主峰 (Percussion wave) と拡張早期隆起 (Dicrotic wave) があげられる. 図 2 の波長 $650 \mathrm{~nm}$ と $810 \mathrm{~nm}$ に おける主峰と拡張早期隆起と波長 $530 \mathrm{~nm}$ における主 峰と拧張早期隆起が上下反転していること (反転現象) がわかる. よって, 光散乱解析結果から反転現象の要 因を調べた.

図 7 は波長 $530 \mathrm{~nm}, 650 \mathrm{~nm}$ と $810 \mathrm{~nm}$ における散乱 光強度変化量 $\Delta \Phi$ を示している. 横軸は発光点位置,

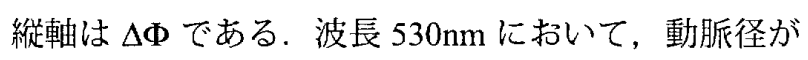
増加した場合に血管の梁さにかかわらず $\Delta \Phi$ は正の值 が確認される.一方, 波長 $650 \mathrm{~nm}$ と $810 \mathrm{~nm}$ において， 血管の深さにかかわらず動脈径が増加した場合に $\Delta \Phi$ は負の值が確認される。一般的に，散乱係数を無視し て皮下脂肪より吸収が大きい血管及び, 血液が設置し ている仮定すると, Beer-Lambert 則に基づき検討する ことが可能である. その場合, 血管径が増加すると光 強度は減少し, 血管径が隇少すると光強度は增加する. しかしながら，本測定，及び解析において波長 $530 \mathrm{~nm}$ で血管径が増加すると $\Phi$ は増加し, 血管径が減少す るとФは減少している.これは, 表 1 で示すように, 血管壁における波長 $530 \mathrm{~nm}$ の等価散乱係数が $650 \mathrm{~nm}$ と $810 \mathrm{~nm}$ よりも高い值を示し，血管壁面における後 方散乱が強く現れたことが要因と考えられる.

また, 図 8 は血管壁を設置していない皮下脂肪と血 液の解析モデルによる波長 $530 \mathrm{~nm}, 650 \mathrm{~nm}$ と $810 \mathrm{~nm}$, 血管深さ $\mathrm{d}=5.31 \mathrm{~mm}$ における散乱光強度変化量 $\Delta \Phi$ を 示している. 縦軸は $-\Delta \Phi$, 横軸は発光点位置である. これより, 全波長において散乱光強度変化 $\Delta \Phi$ は負の 值を示していることが確認される.これは, 図 7(a)の $530 \mathrm{~nm}$ の散乱光強度変化量と正負逆の值を示している 
ことから, 図 7(a) の波長 $530 \mathrm{~nm}$ における血管径の増 加にともなう $\Phi$ の増加は, 血管壁の散乱特性が影響 していると考えられる。

次に, 図7(a) において, $\mathrm{d}=3 \mathrm{~mm}$ の場合に $\mathrm{x}=-2$, $\mathrm{x}=0 \mathrm{~mm}$ より $\mathrm{A}$ で $\Delta \Phi$ が低下していることが確認さ れる.これは動脈が浅く発光部と受光部間の平均光路 上に位置し, 波長 $650 \mathrm{~nm}$ と $810 \mathrm{~nm}$ より動脈の散乱係 数が高い $530 \mathrm{~nm}$ の光源を用いた場合, 血管径が大き いほど光伝播を遮断することが要因と考えられる．こ の傾向は模擬血管を用いたファントム実験においても 模擬血管位置が浅い場合に生じた ${ }^{(9)}$. しかしながら， 測定実験における成人男性の橈骨動脈は $\mathrm{d}=5.31 \mathrm{~mm}$ で あり， $\mathrm{d}=4 \mathrm{~mm}$ より深いところに位置している。した がって，本論文において，動脈位置の探索には影響を 及ぼさないと考えられる.

以上より，図7 の波長 $530 \mathrm{~nm}$ に打ける散乱光強度 変化量 $\Delta \Phi$ が正の值を示している要因は血管壁の散乱 の影響である.したがって, 波長 $530 \mathrm{~nm}$ と $810 \mathrm{~nm}$ の 光電脈波における反転現象の主因は血管壁の散乱の影 響と考えられる.

4.3 超音波脈波形-光電脈波波形の相関性 図 9(a) は超音波脈波波形-各波長の光電脈波波形の決定 係数 $R^{2}$, (b) は超音波脈波反転波形-各波長の光電脈波 波形の決定係数 $R^{2}$ を示している. 縦軸は $R^{2}$ ，横軸は 発光点位置を示している. 図9(a)において, A で波長 $530 \mathrm{~nm}$ の決定係数 $R^{2}=0.72$, 波長 $650 \mathrm{~nm}, 810 \mathrm{~nm}$ の決 定係数 $R^{2}=0.21,0.28$ を示している. 一方, 図 9(b) に おいて，A で波長 $650 \mathrm{~nm}, 810 \mathrm{~nm}$ は決定係数 $R^{2}=0.81$, 0.88 , 波長 $530 \mathrm{~nm}$ は決定係数 $R^{2}=0.40$ を示している. これより A に括いて，超音波脈波波形-波長 $530 \mathrm{~nm}$ の 光電脈波波形の決定係数は高く, 超音波脈波反転波形波長 $650 \mathrm{~nm}, 810 \mathrm{~nm}$ の光電脈波波形の決定係数が高 い. したがって，波長 $530 \mathrm{~nm}$ の波形に対して，650nm と $810 \mathrm{~nm}$ は反転波形であることがわかる.これは波 長 $530 \mathrm{~nm}$ と $810 \mathrm{~nm}$ は 4.2 節の図 7 で示したように散 乱, 吸収特性の違いが決定係数に反映されている.

次に, Aに打いて, 超音波脈波波形-波長 $530 \mathrm{~nm}$ の 光電脈波波形と超音波脈波反転波形,波長 $810 \mathrm{~nm}$, 及 び $650 \mathrm{~nm}$ の光電脈波波形で，決定係数は最大值を示 している.これは，4.2節の図6で示したように，A に扔いて散乱光強度の振幅が最大值であることから， 動脈以外から外乱に対する動脈からの散乱光強度の比 (SN 比)が向上したことが要因と考えられる. したがっ て, 超音波脈波波形-光電脈波波形の決定係数から血 管中心位置が推定可能であることがわかる.

さらに，図9のAに打いて，超音波脈波波形-波長

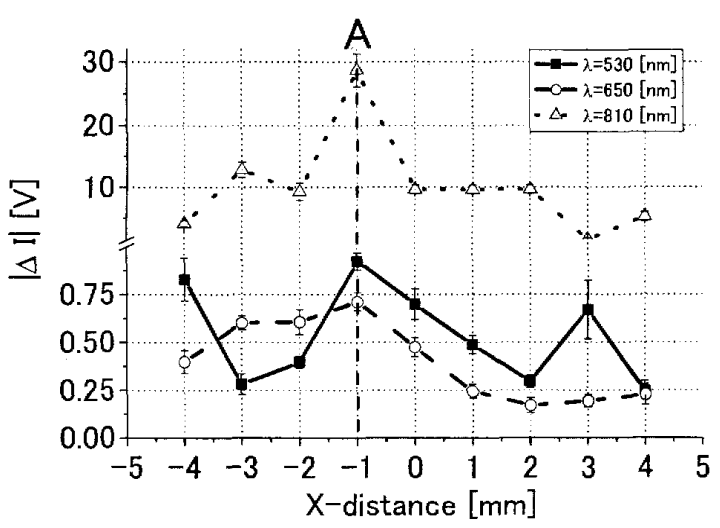

(a)Measurement

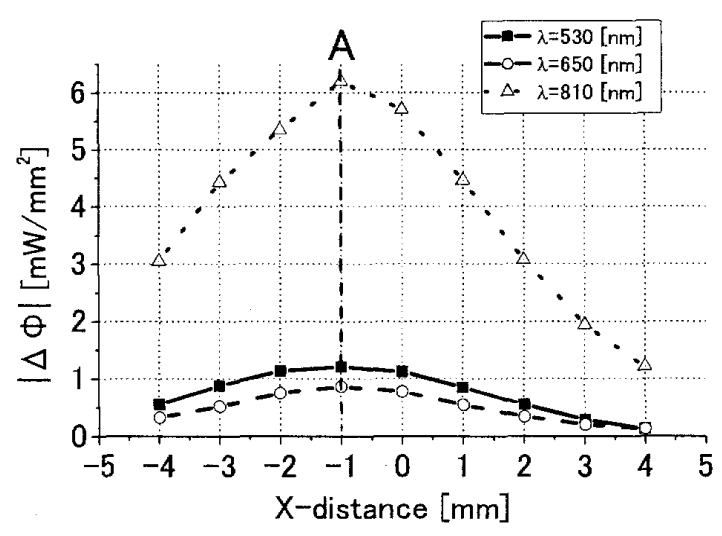

(b)Analysis

Fig. 6 The intensity change amplitude of light scattering.

$530 \mathrm{~nm}$ の光電脈波波形の決定係数は $\mathrm{x}=-2,0 \mathrm{~mm}$ の決定 係数の約二倍を示し，超音波脈波反転波形-波長 $650 \mathrm{~nm}$, $810 \mathrm{~nm}$ の光電脈波波形の決定係数より明確なピーク点 が現れている．この要因として以下が考えられる，皮 膚表面から水平に受発光部固定治具で押さえる脈波測 定実験において，動脈の血管壁部分を扁平にすること で, 動脈壁の張力が除去され, 内压と外圧が等しくな る(3).したがって，扁平にされた動脈の血管壁部分に おいて, 内圧変動が動脈壁の圧迫面に対して垂直方向 に伝わり易くなり，波長 $650 \mathrm{~nm}$ と $810 \mathrm{~nm}$ より透過深 度が短い波長 $530 \mathrm{~nm}$ の光電脈波が皮膚直下の動脈壁 上部の変動を検出していると考えられる

また, Wess らの報告では, 光の平均透過深度 $L=$ $\left(0.475 S D^{1 / 2}\right) /\left(\mu_{a} \mu_{s}^{\prime}\right)^{1 / 4}$ 単位 $\mathrm{mm}$ で表される ${ }^{(16)}$. 皮 下脂肪の場合, 表 1 から算出すると, 波長 $530 \mathrm{~nm}$, $650 \mathrm{~nm}, 810 \mathrm{~nm}$ の光の平均透過深度は $L=0.60 \mathrm{~mm}$, $0.62 \mathrm{~mm}, 0.64 \mathrm{~mm}$ であり, 動脈血管壁位置よりも浅い 


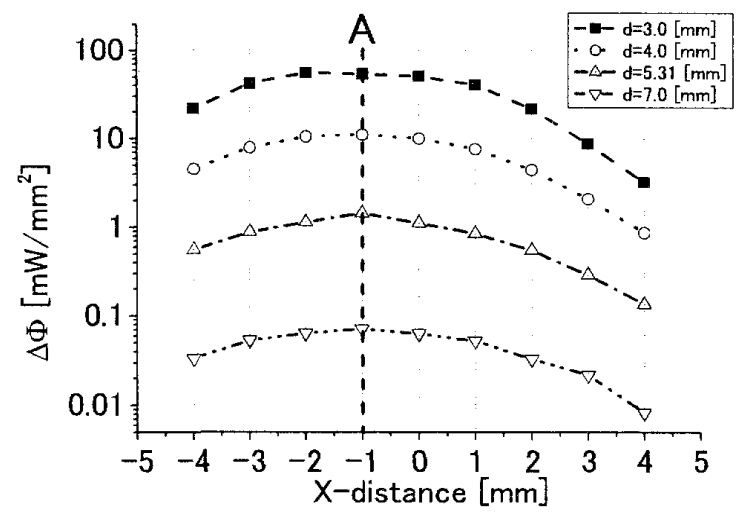

(a) $\lambda=530 \mathrm{~nm}$

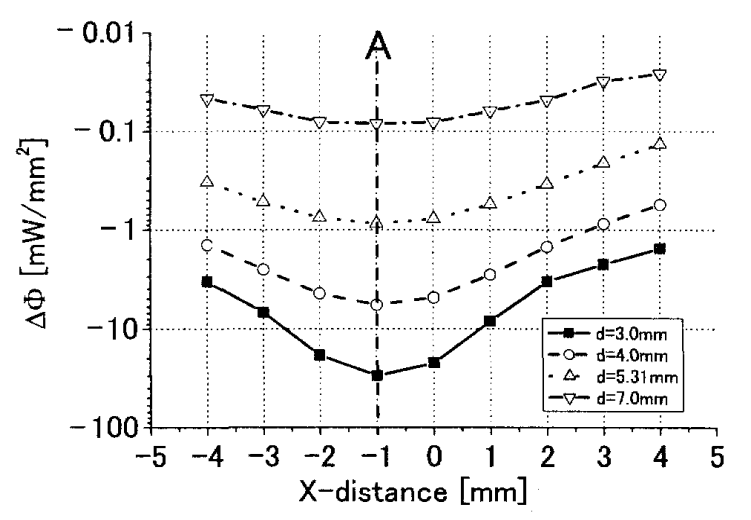

(b) $\lambda=650 \mathrm{~nm}$

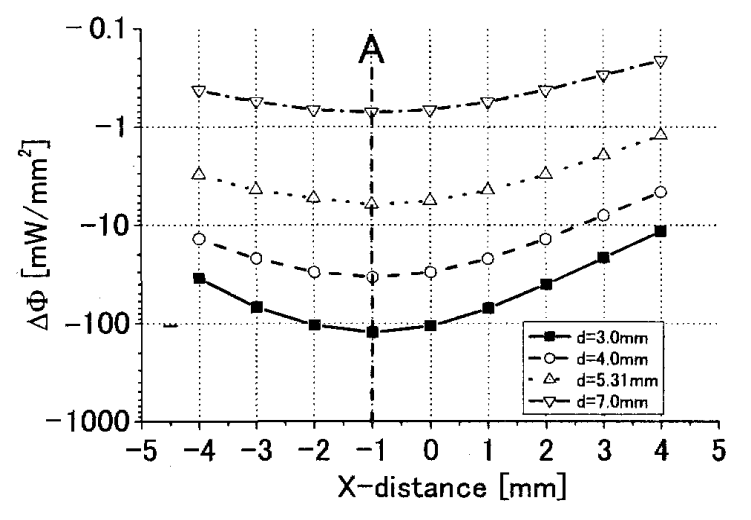

(c) $\lambda=810 \mathrm{~nm}$

Fig. 7 The intensity change of light scattering.

ことがわかる. しかしながら，超音波脈波波形-光電 脈波波形の決定係数を用いて動脈位置を検出可能であ り, 各光電脈波で充分に動脈の動的特性を検出できて いる. よって, 光電脈波は光の平均透過哚度よりも深 い位置の動的特性を光散乱強度として検出しているこ とが考えられる.

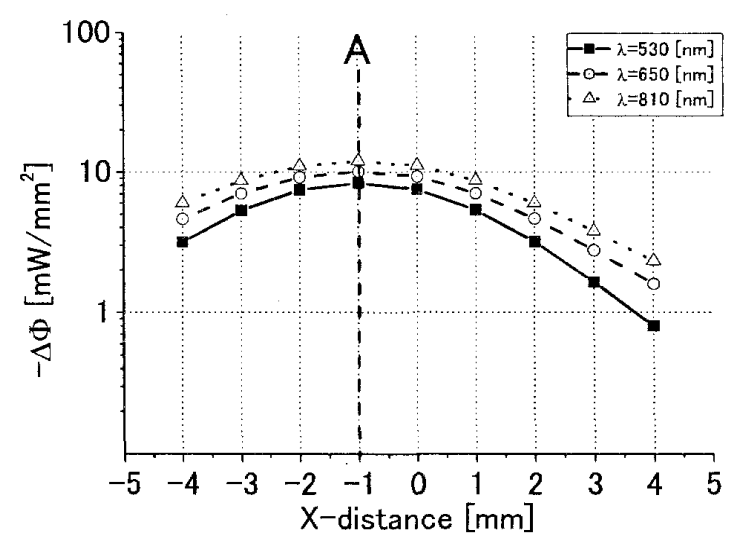

Fig. 8 The intensity change of light scattering in a analysis model without arterial wall.

以上より，超音波脈波波形-波長 $530 \mathrm{~nm}$ の光電脈波 波形の決定係数を用いることで, 動脈位置の探索が可 能であることが示された.

\section{4 二波長光源を用いた動脈位置探査法 4.3 節} より, 超音波脈波波形-波長 $530 \mathrm{~nm}$ の光電脈波波形は, 動脈位置の探查に利用可能であることがわかった。し かしながら，実際の測定を想定すると超音波による 脈波測定は高コストとなるため, 光電脈波のみで血 管位置探索が必要と考えられる. そこで，血管の真上 に受発光中心位置がある場合，超音波脈波波形-波長 $810 \mathrm{~nm}$ の反転波形の決定係数は $R^{2}=0.88$ で高い相関性 を示すことから, 二波長 $810 \mathrm{~nm}$ の光電脈波反転波形波長 $530 \mathrm{~nm}$ の光電脈波波形の決定係数を用いる動脈 位置探索法を検討する.

図 10 に波長 $810 \mathrm{~nm}$ の光電脈波反転波形-波長 $530 \mathrm{~nm}$ の光電脈波反転波形の決定係数 $R^{2}$ を示す. 縦軸は $R^{2}$, 横軸は発光点位置を示している. 図 10(a) より決定係 数 $R^{2}<0.7$ を示しているが, 図 10(b) より A において, 決定係数の最大值 $R^{2}=0.92$ であり, $\mathrm{x}=-2,0 \mathrm{~mm}$ の決定 係数の二倍以上の值を示し, 明確なピーク点が現れて いる. したがって，二波長 $810 \mathrm{~nm}$ の光電脈波反転波 形-波長 $530 \mathrm{~nm}$ の光電脈波波形の決定係数による血管 估置の推定は利用可能であることが示された.

以上より，本論文において，試作した受発光間隔を $2 \mathrm{~mm}$ の反射型光電センサを用いて，二波長 $810 \mathrm{~nm}$ の 光電脈波反転波形-波長 $530 \mathrm{~nm}$ の光電脈波波形の決定 係数から血管位置が推定可能であることを示した，本 方法は血管の膨張期, 収縮期の散乱光強度変化を测定 し, 異なる二波長の光電脈波波形から動脈位置を探索 するため，生体内の動的な特性を検出しているといえ る.したがって, 静脈の影響が少なく, 動脈探查に適 


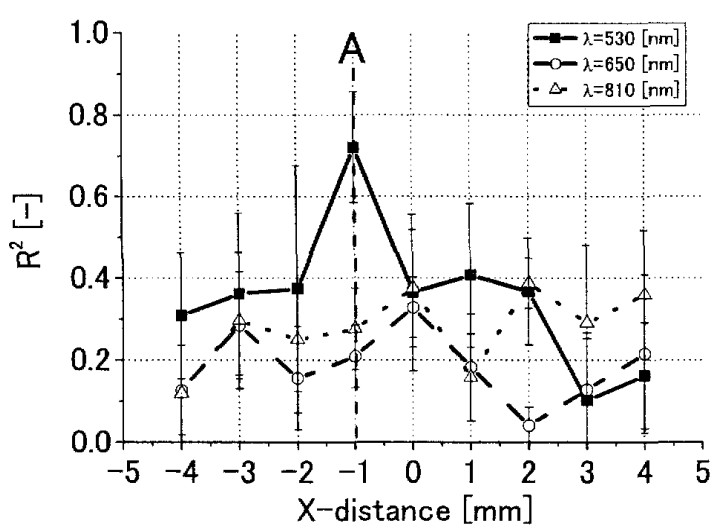

(a)Pulse Wave

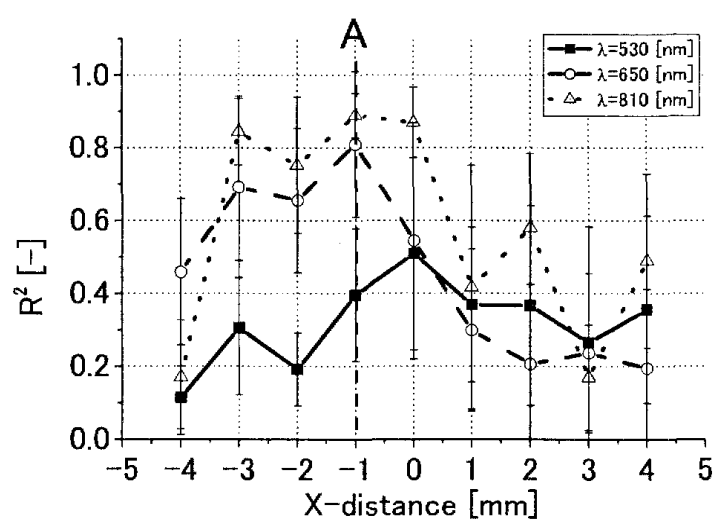

(b)Inversion Pulse Wave

Fig. 9 The determination coefficient of photoplethysmograhy and ultrasonic pulse wave.

していると考えられる. しかしながら, 測定実験にお いて，反射型光センサの受発光間隔を $2 \mathrm{~mm}$ とし，対 象者の動脈深さが一定であるため, 動脈深さが変化し た場合に対する本手法の限界, 受発光間隔を変化さ せた場合の光電脈波波形の特性，光学特性の個体差を 含めた動脈位置検出精度に関して検討していく必要が あるが, 今後の課題としたい.

\section{5. 結論}

本論文で得られた結論は以下のとおりである.

(1) 波長 $530 \mathrm{~nm}$ の光電脈波と波長 $650 \mathrm{~nm}$, 及び $810 \mathrm{~nm}$ の光電脈波の波形が反転する現象 (反転現象) を用いた非侵意動脈位置探査法を提案した。

(2) 橈骨動脈モデルを用いた光散乱解析から反転現 象の要因を明らかにし，橈骨動脈を対象とした光電脈 波測定実験から反転現象を確認した。

（3）橈骨動脈を対象とした光電脈波測定実験から

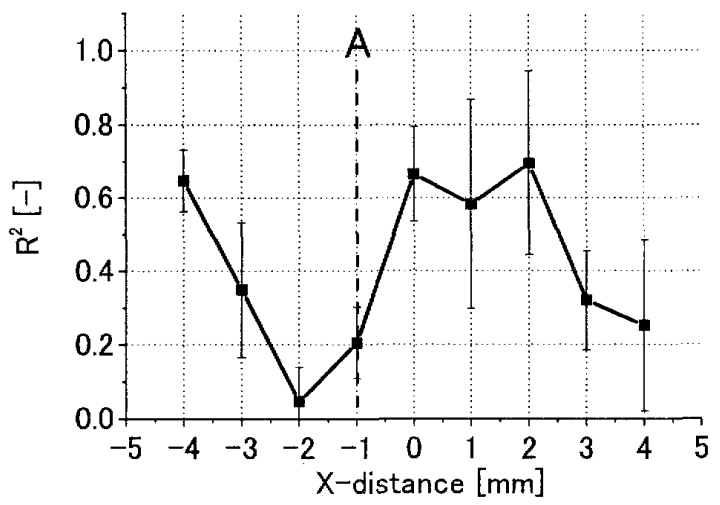

(a)Pulse Wave

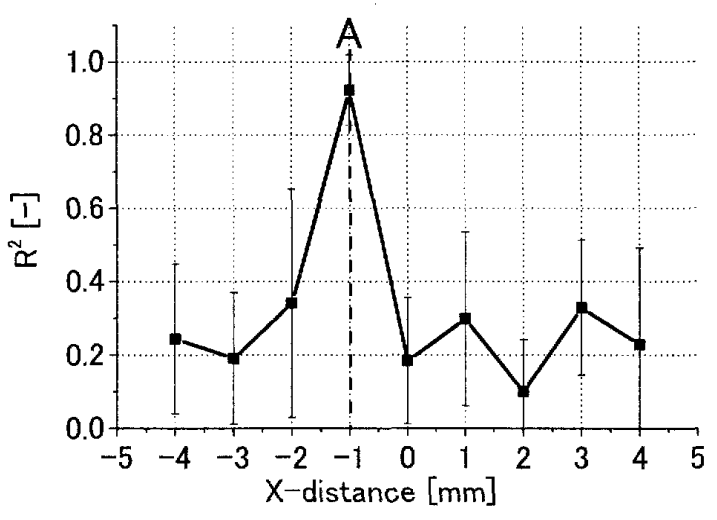

(b)Inversion Pulse Wave

Fig. 10 The determination coefficient of $\lambda=530 \mathrm{~nm}$ photoplethysmograpy and $\lambda=810 \mathrm{~nm}$ photoplethysmograpy.

$530 \mathrm{~nm}$ と $810 \mathrm{~nm}$ の二波長を用いて動脈位置の推定が 可能であることを示した。

\section{謝辞}

本研究は, 知的クラスタ一創成事業にかかわる事業, やまぐち・うベメディカル・イノベーション構想の援 助を基になされました。ここに付記して謝意を表しま す.また，本研究の実験装置の作製にご協力を賜った 株式会社オプトテクノ村田氏に心よりお礼申し上げ ます．最後に，本研究の遂行にあたり貴重なご助言を いただいた東京医科歯科大学生体材料工学研究所 高 谷節雄教授に深く感謝致します。

\section{文献}


(1) Ota, S., Yasuda, T. and Saito, T., Transactions of the Japan Society of Mechanical Engineers. Series C, 74, (2008-7), pp1849-1856.

(2) Ota, S., Yasuda, T. and Saito, T., Proceedings of the 46th Regular Meeting of Transactions of the Japanese Society for Medical and Biological Engineering, Kobe, May 8-10, 46, 2008, pp251.

(3) Saito, T., Nishinaga, M., Kawamoto, A., Ozawa, T. and Takatsuji, H., Hypertension, 21(6), Part 1, (1993), pp866874.

(4) Fridokin, I. and Lindberg, L-G., Phys. Med. Biol, 45, (2000), pp3765-3778.

(5) Fridokin, I., Hansson, K. and Lindberg, L-G., Phys. Med. Biol, 45, (2000), pp3779-3792.

(6) Ozawa, T., Asano, K., Numada, S., Hasui, Y., Kouchi, Y. and Ishihara, K., Transactions of the Japanese Society for Medical and Biological Engineering, 43(1), (2005), pp93102.

(7) Nakamachi, E., Kuroda, T., Tsuchiya, K., Uetsuji, Y. and Uenoya, T., Transactions of the Japan Society of Mechanical Engineers. Series C, 73(731), (2007-7), pp2088-2089.

(8) Yasuda, T., Ouchi, K., Yoshida, M. and Takatani, S., Proceedings of the 44th Regular Meeting of Transactions of the Japanese Society for Medical and Biological Engineering, Tsukuba, Apr 25-27, 43(1), 2005, pp516.

(9) Ota, S., Iwamoto, K., Yasuda, T., Takatani, S. and Saito, T., Proceedings of the 46th Chugoku-Shikoku Branch Regular Meeting of the Japan Society of Mechanical Engineers, Hiroshima, March 7, 85(1), 2008, pp 19-20.

(10) Duderstadt, J. J. and Hamiton, L. J., Nuclear Ractor Analysis, John Wiley \& Sons, New York, (1976).

(11) Hayashi, K., Biomechanics., (2000).

(12) Roggan, A., Friebel, M., Dorschel, K., Hahn, A. and Muller, G., Journal of Biomedical Optocs, 4(1), (1999), pp36-46.

(13) Bashkatov, A. N., Genina, E. A., Kochubey, V. I. and Tuchin, V. V., Institute of Physics Publishing, 38, (2005), pp2543-2555.

(14) Keijzer, M., R. Richards-Kortum, R., Jacques, S. L. and Feld, M. S., Appl. Opt, 28, (1989), pp4286-4292.

(15) Cui, W., Ostrander, E. Lee. and Lee, Y. B., IEEE Transactions on Biomedical Engineering, 37(6), (1990), pp633-639.

(16) Weiss, G., Nossal, R. and Bonner, R., J. Modern Opt., 36(3), (1989), pp349-359. 